\title{
Homeobox Protein SIX4
}

National Cancer Institute

\section{Source}

National Cancer Institute. Homeobox Protein SIX4. NCI Thesaurus. Code C111810.

Homeobox protein SIX4 (781 aa, $\sim 83 \mathrm{kDa}$ ) is encoded by the human SIX4 gene. This protein plays a role in both transcription regulation and eye development. 